\title{
Why Czech Parliamentary Party Groups Vote Less Unitedly. The Role of Frequent Voting and Big Majorities in Passing Bills*
}

\author{
LUKÁŠ LINEK and PETRA RAKUŠANOVÁ** \\ Institute of Sociology, Academy of Sciences of the Czech Republic
}

\begin{abstract}
The article aims to explain voting unity in the Chamber of Deputies of the Parliament of the Czech Republic based on data from the years 1998-2002. It introduces the basic terminology and theoretical framework used in literature on the behaviour of parties in parliament and the basic institutional rules that should result in the unity of political parties in the Czech parliament. It then presents the data used to measure the unity of Czech parliamentary party groups. The initial assumption that specific institutional factors found in parliament and in political parties would lead to greater PPG unity in the Czech Republic was not confirmed. Although the institutional incentives are similar to those in Western European countries, they do not secure the same level of voting unity in Czech PPGs. The authors conclude that the relatively low party unity is caused by the size of the voting coalitions that pass individual bills.

Sociologický časopis/Czech Sociological Review, 2005, Vol. 41, No. 3: 423-442
\end{abstract}

There is a tendency to describe contemporary democracies as party governments [e.g. Castles and Wildenmann 1986], where political parties play a key role in organising the election contest, selecting candidates for public office, and forming a government on the basis of a parliamentary majority. These roles are codified and documented in the constitutions and laws that regulate the election contest and the way in which political parties operate. Theories of parliamentary democracy and party government assume the existence of unified voting blocks in parliament, or, more precisely, unified parliamentary party groups $\left(\mathrm{PPGs}^{1}\right)$. Shaun Bowler, David

* The work this article is based on was supported by research project no. AV0 Z70280505 'The Sociological Analysis of Long-term Social Processes in Czech Society, 2005-2010'. This article is an abbreviated and in places substantially re-worked version of a study, to which the authors sometimes make reference for more detailed description or argumentation [Linek and Rakušanová 2002].

** Direct all correspondence to: Lukáš Linek, Institute of Sociology, Academy of Sciences of the Czech Republic, Jilská 1, Prague, 110 00, Czech Republic, e-mail: Lukas.Linek@soc.cas.cz; Petra Rakušanová, Institute of Sociology, Academy of Sciences of the Czech Republic, Jilská 1, Prague, 110 00, Czech Republic, e-mail: Petra.Rakusanova@soc.cas.cz.

${ }^{1}$ Knut Heidar and Ruud Koole [2000b: 249] define parliamentary party groups as "an organised group of members of a representative body who were elected either under the same

(C) Sociologický ústav AV ČR, Praha 2005 
Farell and Richard Katz [1999] pointed out that for most authors this assumption has acquired a normative status. The unity of PPGs and parties is considered a precondition for the functioning of basic democratic mechanisms like representation and accountability. If the elected MPs of one party are to represent the programme that they were elected to promote and advance, then they should assert it jointly and in union. It should not be that one group in a party advances the opposite of that which the second group is promoting. Moreover, if the mechanism of accountability is to be applied, then parties ought to be trying to seek re-election and the renewal of their mandate. But how can voters evaluate the activity of political parties in elections when it is impossible to detect from the actions of their MPs which viewpoints they represent, and when one section has supported something other than another section [e.g. Mulgan 2003; Przeworski 1999]?

The main objective of this article is to examine party unity and to explain the reasons that lie behind the voting unity of Czech PPGs. The article is based on voting data from 1993-2002 and data from a longitudinal survey conducted among the MPs of the Chamber of Deputies of the Czech parliament during the same period. It begins by introducing the basic terminology that is used frequently in debates on the behaviour of parties in parliament, i.e. the concepts of unity, cohesion and discipline, and the methods used to measure these concepts in parliamentary research. This is followed by an explanation of the article's theoretical framework, which suggests possible reasons why parliamentary political parties vote in unison. This theoretical framework draws mainly on the work of Reuven Hazan [2004] and Shaun Bowler [2002], and is based on the idea that MPs' role perception, and therefore also their behaviour and voting, is shaped by the structure of opportunities that exists for meeting their basic strategic objectives, which are re-election and advancement up the parliamentary party ladder. In the next section the authors present the basic institutional rules, which determine the success of MPs in achieving their aims, and which should produce unity within political parties in the Czech parliament. The authors also present data on the unity of Czech PPGs to introduce and discuss the factors that contribute to reducing voting unity.

\section{Semantics and the theoretical approaches used to conceptualise the unity of PPGs}

In parliamentary and party research there are several terms that are used to describe the unity of action of a group of MPs: party unity (as opposed to party dissent), party discipline, and party cohesion. In this article we re-conceptualise the semantic

party label or under the label of different parties that do not compete against each other in elections, and who do not explicitly create a group for technical reasons only". In references to PPG the authors have in mind the equivalent of the Czech term poslanecký klub or senátorsky klub, the German Fraktionen, and the English terms parliamentary parties, parties in parliament etc. 
foundation and arrangement of relationships between these terms as put forth by Ergun Ozbundun. Ozbundun defines party cohesion as "the extent to which, in a given situation, group members can be observed to work together for the group's goals in one and the same way" [Ozbundun 1970: 305], while in his opinion, party discipline means that "followers regularly accept and act upon the commands of the leader or leaders". Party discipline also refers to the "ways and means of inducing recalcitrant members to accept and act upon (leader's) commands". Therefore, discipline "refers either to a special type of cohesion achieved by enforcing obedience or to a system of sanctions by which such enforced cohesion is attained" [Ozbundun 1970: 305]. Ozbundun uses the first term to define the second term and vice versa, and arranges these two terms in a hierarchical relationship where discipline is subsumed in cohesion, i.e. he sees discipline as part of cohesion. In his view then cohesion means "an objective condition of unity of action among party members, which may or may not be the function of disciplinary repressions" [Ozbundun 1970: 305].

Ozbundun does not terminologically address the possibility that a PPG may act in unity without needing to employ discipline. But if the aim is to understand how PPGs function and to analyse the unity of PPGs, it is hazardous to neglect this possibility. For the purposes of this article [see also Hazan 2004] Ozbundun's terms are re-conceptualised so that party unity means the observed unity of party members' actions or the unity of PPG actions (Ozbundun's cohesion). Party unity may then be the result of both party cohesion and party discipline. Cohesion and discipline should and must be differentiated as terms, but it is hard to agree with Ozbundun's proposition that discipline is a special type of cohesion, a subgroup of cohesion. As terms, cohesion and discipline differ analytically because they conceptualise party unity from two complementary, but nonetheless different points of view. If party unity is a result of party cohesion it is a consequence of an un-coerced decision by PPG members resulting from the fact that they hold similar opinions. It entails objective unity in the sense that it does not have to be coerced. However, if party unity is the result of party discipline then it is a consequence (1) of the use of coercive means that either the party executive or the PPG leadership have at their disposal to enforce unity/discipline, or simply (2) of how MPs perceive these means or the opportunity structure.

When a PPG acts in unity, it may be because its members agree on the party position (party cohesion), or it may be because they were forced to act that way, even though their personal preferences were different (party discipline). There are many ways of persuading MPs to vote in a way other than their original intentions: party or PPG leadership recommendations, motivating MPs with rewards in the form of appointments or election to a position, or motivating MPs with rewards from interest groups, etc. This conceptualisation has the advantage of differentiating analytically between the terms cohesion, unity, and discipline. ${ }^{2}$ Ozbundun's co-

\footnotetext{
${ }^{2}$ A disadvantage of this conceptualisation (and of Ozbundun's) is its static nature, and as a result it is unable to address the fact that the unity of parliamentary party groups in voting
} 
hesion, which encompasses unity and cohesion, as used here, provides no analytical tools for understanding un-coerced unity of attitudes. In our notion, party cohesion is understood as a condition of collective action, where the party or PPG leadership does not have to work to ensure unity. This kind of collective action is far less costly in terms of the transaction costs for the party leadership, and as such it may be given deliberate priority. Conversely, by introducing a specific agenda it is possible to ensure that no issues on which a party is not cohesive, and which would entail large transaction costs for the leadership in trying to achieve unity, are presented in parliament. ${ }^{3}$ These three concepts can be examined and measured with different tools. For example, cohesion can be studied through questionnaire surveys of MPs designed to reveal MPs' attitudes toward individual public policies. By classifying the responses according to their PPG membership, it is possible to create a map of party cohesion. It is possible to measure unity using Rice's Index of Party Cohesion or using other indexes [see Appendix 2 in Linek and Rakušanová 2002]. Discipline can be analysed by examining the tools used to maintain unity among MPs (see Figure 1).

Reuven Hazan [2004] linked the theoretical distinction between cohesion and discipline as two sources of unity with two basic theoretical approaches traditionally used in parliamentary research to explain party unity. He terms the first the sociological approach, which stresses norms and roles. According to this approach MPs act in unity for normative reasons, for example, owing to ideological conviction, political socialisation, or party solidarity. Authors who support this approach underline the role of informal rules, such as loyalty and solidarity, which restrain MPs' behaviour. Conversely, the institutional approach stresses strategic incentives and restrictions and finds the main cause of party unity in the formal arrangements of political parties and parliaments and in the rational conduct of MPs aimed at maximising their utility. Parliaments and parties control the distribution of influence, benefits and re-election. According to Hazan [2004], PPGs achieve unity provided that their members share sufficiently strong views in common; these are noninstitutional reasons (the sociological approach). When party cohesion begins to

is a dynamic phenomenon, where cohesion and discipline combine with internalised norms of partisanship. This internalisation refers to the fact that MPs generally do not question or contemplate voting in unity because they consider it right and normal to do so. While MPs give strategic consideration to deviating from a party position, and thus breaching the partisanship norm, they do not contemplate their regular conformity. The partisanship norm can be understood as the exercise of disciplinary power [e.g. Weber 1972: 681-682; Foucault 1975: Chapter 3], i.e. the uniform and general, rationalised and methodically practised execution of accepted orders without the least sign of criticism. In a sense this involves both cohesion (the un-coerced decision to act in unity) and the exercise of discipline (the partisanship norm puts external pressure on MPs' conduct).

${ }^{3}$ It may be expected that party A will intentionally introduce an agenda on which party B is not cohesive and it will consequently force the leadership of party B to either demand a unified vote from its MPs or consent to disunity. 
Figure 1. Conceptualisation of the terms unity, cohesion and discipline

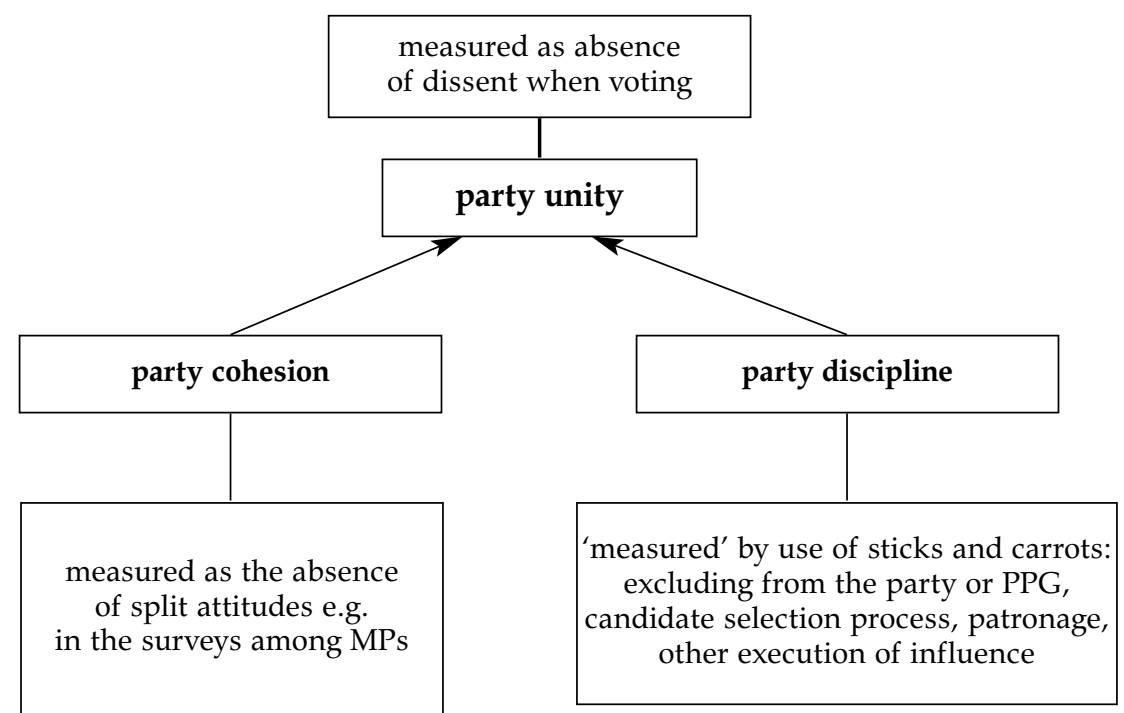

break down, there is a need for institutional mechanisms to keep the party together, and this is where discipline comes into play (the institutional approach).

Unlike Hazan, Shaun Bowler prefers the institutional approach and does not consider the sociological approach to be relevant for explaining the unified behaviour of parliamentary party members. Bowler divides the explanations that Hazan includes under the institutional approach into two groups, according to the arenas in which they seek to explain parliamentary party unity - a two-arena model and a onearena model [Bowler 2002]. The one-arena model highlights the role of incentives and instruments within parliament to explain the unity of parliamentary party groups (the legislative arena). These incentives include nominating members for particular positions, procedural advantages that make it possible to influence the agen$\mathrm{da}$ and thus also policy, and benefits and offices. The two-arena model stresses the importance of the electoral competition as the factor that shapes the behaviour of politicians. Unified PPGs are seen as a consequence of the need to compete and win the elections, and political parties provide the basic tools for doing this: a label, funding, advice or organisation (the electoral arena explains the legislative arena). Bowler demonstrates that the two-arena model is capable of explaining the existence of party unity in parliaments when it also focuses on the incentives provided by the candidate selection process within party organisations [Bowler 2002: 176-179].

In this article Bowler's analytical framework is used to analyse the unity of Czech parliamentary parties, taking advantage of the fact that the shared norms and 
attitudes (party cohesion) may but need not necessarily contribute to party unity. Conversely, if there is less cohesion, institutional incentives should ensure unity of PPGs. The focus therefore lies on the key elements in the one-arena and two-arena models, i.e., the political and electoral systems, the process of candidate selection in political parties, and parliamentary procedures. These are the institutions that make it possible for MPs to achieve their three basic strategic objectives: re-selection, reelection and advancement up the parliamentary party ladder [Gaines and Garrett 1993: 116].

\section{Institutional and procedural incentives for party unity}

The electoral arena: the political and the electoral system and the candidate selection process in Czech parties

The Czech Republic has a parliamentary system and a cabinet structure of government. On the basis of the results of an election political parties negotiate over the construction of a cabinet, which must be capable of securing majority support in the Chamber of Deputies [Mansfeldová and Müller-Rommel 2001]. Jan Kysela describes the Czech political system as parliamentarism without the rationalising elements that strengthen the position of the cabinet in relation to the Chamber of Deputies [Kysela 2003]. Therefore, it is crucial to the formation and maintenance of the cabinet that there is united support for the cabinet in the ruling PPGs. After winning a confidence vote the government is faced with the task of governance, which in modern societies is exercised primarily through the passage of acts and through legislation in general. Consequently, here again the government is dependent on the support of the PPGs and remains so for its entire electoral term. This dependence grows in relation to the position of the government in the legislative process; neither the Constitution nor the Rules of Procedure ascribe any formal privileges to the cabinet in proposing and negotiating acts [see also Kopecký 2000].

After the 1998 elections in the Czech Republic the minority Social Democratic cabinet managed to hold office for the full duration of its term (1998-2002) with the help of the 'Agreement on Creating a Stable Political Environment in the Czech Republic', which was signed between the Czech Social Democratic Party (ČSSD) and the Civic Democratic Party (ODS). For ČSSD the agreement guaranteed a stable cabinet and that ODS would neither initiate a vote of 'no confidence' against the government nor support any such vote. For ODS the agreement guaranteed its involvement in the appointments to important political positions, consultations with the government prior to their making important decisions, and above all, the consent of CSSD for the expansion of the majority elements in the electoral system and a limitation on the powers of the President of the Republic. The government was put in a position that forced it to negotiate support for each bill in the Chamber of Deputies.

In 1998 MPs were elected under the Electoral Act of 1995, in a proportional system with eight electoral districts and with between 20 and 60 candidates on par- 
Table 1. The composition of PPGs in the third electoral term (1998-2002)

\begin{tabular}{lc}
\hline Party & Number of members \\
\hline Civic Democratic Party (ODS) & 63 \\
Communist Party of Bohemia and Moravia (KSČM) & 24 \\
Czech Social Democratic Party (ČSSD) & 74 \\
Christian Democratic Party - Czechoslovak People's Party (KDU-ČSL) & 20 \\
Freedom Union (US) & $19(18,17)$ \\
Total number of MPs & 200 \\
\hline
\end{tabular}

Source: Chamber of Deputies, Parliament of the Czech Republic.

ty lists, depending on the size of the district (see Table 1 for the composition of the Chamber of Deputies). This proportional system was based on the HagenbachBischoff electoral formula applied in two scrutinies. Candidates could only be put forth by political parties, political movements, or coalitions of the two. Parties had to obtain at least five percent of the votes nationally, a coalition of two parties had to gain seven percent, a coalition of three nine percent, and a coalition of more than four eleven percent of the votes. The party lists were binding but not strictly binding. A voter could vote for only one party list but within that party list could state his/her preferences for as many as four candidates. In the 1998 elections, if a candidate received more than ten percent of the preference votes, the candidate was considered to have won a preferential mandate in the given district. In 2002 MPs were elected according to similar rules.

Candidate selection in individual political parties is a reflection of the electoral system, and political parties prepare party lists according to the number of electoral districts. The political parties represented in a given term in the Chamber of Deputies employ a process of decentralised candidate selection, where county and regional party organisations select candidates and determine their rank, with a lesser or greater degree of interference from the central bodies. Between 1998 and 2002 parties adopted two basic candidate selection models: (1) a decentralised decision-making model, where a regional nomination convention or party members in the electoral district decided on candidates and their rank (KDU-ČSL, US-DEU); (2) a pyramid model with three or more selection levels (from local through county, regional and national levels), in which a large role is played by party executive bodies at each level (ČSSD, KSČM and ODS) [Saxonberg 2003; Outlý 2003]. In all parties, the support of regional leadership or the support of members at the regional level is crucial for an MP's re-election, and this applies even when national party bodies interfere in the candidate selection process, as they are large party bodies whose formation is based on regional representation. This means that MPs who oppose the party leadership or PPGs, but whose position in the regional party organisation is at the same time strong, can be re-selected for the party list. 
In sum, the functioning of the political system requires and assumes the unity of PPGs, otherwise the position of the cabinet would be weak and the cabinet would be unable to push policies through the legislature. An electoral system in which the only way to be able to stand for office is to be selected for the party list strengthens the dependence of MPs on political parties. On the other hand, an electoral system that has preference voting and a candidate selection process does not necessarily require that MPs only vote in line with party leadership. The strong position of some MPs in regions means that it is possible to ensure re-election despite disagreement with the party leadership or the parliamentary party group.

\section{The legislative arena: procedures, voting, and appointments in the Chamber of Deputies}

Within the legislative arena there are many parliamentary rules and institutional structures that have the capacity to increase the unity of parliamentary political parties. Here we will focus on just some of them: the procedural advantages of parties in the legislative process, mechanisms of appointments in the parliament and the status of parties in the parliament. In this regard, a key aspect is the official recognition of a group, which is followed by the allocation of special privileges and resources to that group. The Rules of Procedure valid since 1995 do not legally define the PPGs as bodies of the Chamber of Deputies; but in practice they are. The Rules of Procedure stipulate that MPs may associate in PPGs on the basis of their affiliation to political parties and to political movements on whose list they ran in the elections. This definition is stricter than in the previous Rules, which stipulated that MPs may associate in parliamentary party groups on the basis of their political opinions. The minimum number of MPs required to form and run a parliamentary party group is ten, which is double the number required before 1995. The internal workings of PPGs are not regulated in any way, except for the accounting of their expenditures [see also Šimíček 1996; Kolář, Pecháček and Syllová 2002].

The Rules of Procedure stipulate that MPs from one political party can create only one PPG. This is one of the provisions restricting the establishment of new PPGs. It is a safety mechanism against spin-off factions, which could then obtain contributions for their activities from the Chamber of Deputies and could present themselves under the same party name as the original PPG and as proponents of party policy. ${ }^{4}$ The Rules of Procedure allow for the formation of new PPGs, which can be composed of MPs affiliated to a political party other than the party for which they were elected or of unaffiliated MPs. The new PPGs are not entitled to funds from the budget of the Chamber of Deputies to cover their costs. ${ }^{5}$ However, they are

\footnotetext{
4 The 1995 Rules of Procedure helped to resolve the issue of the fragmentation of PPGs. Between the first and second electoral term (1993-1996 and 1996-1998) inter-party mobility dropped significantly, and there was a further decline between the second and third terms [see also Linek and Rakušanová 2002; Linek 2001].

5 The Chamber of Deputies approves the rules for the financial management of PPGs every year based on a proposal from the Organisation Committee. The rules of financial manage-
} 
permitted to use the premises and facilities of the Chamber of Deputies. These new PPGs are not entitled to proportionate representation in the bodies of the Chamber of Deputies, i.e. in committees or commissions, unless the Chamber of Deputies decides otherwise. This last point puts limits on establishing new PPGs [see also Linek and Rakušanová 2002; Linek 2001; Mansfeldová 2002].

In addition to the status and related resources of PPGs, the procedural advantages that these groups enjoy in the legislative process also influence the unity of PPGs. On the other hand, granting procedural authority to individual MPs is a strong incentive for these MPs to adopt more independent positions. In addition, the cabinet and groups of MPs, individual MPs, the Senate and regional boards of representatives are also authorised to submit bills. The role of individual MPs in the legislative process is significant from another perspective, too: amendments to bills may be submitted by individual MPs, both in the plenary session and in committee sessions.

The legislative process strengthens the role of PPGs as the main generator of positions on proposed bills. There are three readings in the legislative process. After debating a bill in its first reading during the plenary session, it is debated in the committees. In its second reading, amendments to the debated bill are submitted by individual committees and MPs. In its third reading a vote is taken on the proposed amendments. The first reading is of crucial importance for the fate of each bill because it is at this point that individual parties present their positions on the bill and the debate becomes polarised into proponents and opponents of the bill. If the sequence of approval of bills were different, that is, first in the committees and then in the plenary session, there might be less polarisation between proponents and opponents. As a result, polarised political attitudes precede the potentially less politically polarised discussion of the bill in the committees. If the sequence of the approval of bills were different, that is, first in the committees and then in the plenary session, there might be less polarisation between proponents and opponents. The Rules of Procedure allow for 'an abbreviated debate of bills', wherein a bill may be adopted in its first reading. If two PPGs raise an objection, a bill cannot be passed in the first reading. PPGs also have the power to intervene in the debate, as the chair of a PPG chair has the right to demand the floor at any time and present the opinion of the PPG, or to request an interruption of a session for the purpose of consultation within the PPG.

There is another weighty privilege in the voting rules that may or may not contribute to party unity in parliament. In secret voting, unity may be relaxed, and this may be so even during key or negotiated votes because parties do not have the tools to impose discipline. On the other hand, open voting is an instrument that enables party whips to ensure unity. The Rules of Procedure lay out the methods and rules pertaining to voting in the Chamber of Deputies and they define two possible voting methods: open-public and secret. The method of voting to be used is proposed

ment specify the amount of funding and establish the conditions for obtaining, drawing on, accounting for, and auditing funds received. PPGs that are not in the government are entitled to 1.3 times the standard amount of funding [for more detailed information see Kunc 2001]. 
by the chair of the session. Secret voting is employed to elect the chair and deputy chairs of the Chamber of Deputies, and the chair and deputy chairs of committees. It may also be used in other cases when the chair of the Chamber proposes its use and the Chamber agrees. In secret voting, voting tickets are distributed to all MPs in attendance, who then write the name of their candidate on the ticket. The quorum is calculated according to the number of voting tickets issued. Open-public voting is held in all other cases and may take the form of an electronic vote or roll-call vote. In a roll-call vote, the names of MPs are read aloud in alphabetical order, starting with the letter drawn by the chair. MPs then indicate whether they abstain, are in favour of, or are against a proposal. In an electronic vote, MPs first register using the voting card and then vote for or against a proposal by pressing a button on the electronic voting device within a time period set by the chair.

PPGs also have considerable constitutive power when the bodies of the Chamber of Deputies are being established, i.e. in putting together the committees and commissions and in the appointment of the chair and deputy chairs of the Chamber, and in overseeing the organisation of the sessions of the Chamber of Deputies through the Organisational Committee. PPGs are the only bodies that can nominate candidates for the positions of the chair and deputy chairs of the Chamber and as members of committees and commissions. Committee positions are filled proportionately to the number of MPs in a PPG; MPs who are not members of any PPG cannot be nominated for any position unless they offer their mandate to a PPG, which then negotiates membership in a committee on behalf of the unaffiliated MP. If the number of members in a committee allocated to a given PPG is smaller than the PPG's list of nominees, the rank in which the members of the PPG were nominated decides their appointment. Nominations for chairs of committees and commissions may be submitted both by PPGs and individual MPs. Committees elect a chair from among their members, but the chair must be approved by a majority of the Chamber of Deputies. Generally, however, coalition agreements signed by political parties prior to the formation of a cabinet stipulate the number of members to be named to committees and as specific chairs. The chairs and deputy chairs of the Chamber of Deputies are elected in a secret vote, while the number of committee members and their chairs are decided in an open vote; committee members are confirmed in a vote at a session. A member may be recalled by means of a majority vote in the Chamber of Deputies.

From this overview of the legal status of PPGs it is clear that the ability of those who are not members of a PPG to have any impact on the workings of the Chamber of Deputies is very limited. Unless the Chamber decides otherwise, only PPGs established at the beginning of the electoral term and affiliated to a party elected to the Chamber of Deputies are entitled to be proportionately represented in the bodies of the Chamber of Deputies. If no PPG nominates an MP to sit in a committee, or if a PPG decides that the MP should not be a member of any committee, it may happen that the MP does not become a member of any committee. The fact that the votes are public makes it possible for the PPG leadership to draw 
the attention of other party members and the public to the dissenting behaviour of individual PPG members against their PPG. For MPs who view their political career in a long-term perspective, any deviation from the position of the party or PPG leadership, and from the PPG's positions could well put an end to their political career or at least slow it down.

\section{Why is there less unity among Czech PPGs?}

Having dealt with the basic institutions of the electoral and parliamentary arena that can contribute to strengthening the unity of Czech PPGs, we can now proceed to the analysis of their unity, which is restricted to the most easily measured variables - the Rice Index of Party Cohesion and abstentions. This information is supplemented with findings from questionnaire surveys conducted among MPs. The validity of this approach is supported by the findings of Edward Crowe, who, using a questionnaire survey in the British House of Commons, defined votes against a party position and abstentions as the two most prominent manifestations of disunity [Crowe 1983]. Clearly there are also other ways of demonstrating disagreement, for example, by providing the media with critical texts and interviews, giving critical speeches inside or outside parliament, and expressing disagreement within a PPG, privately to the chair of the PPG, or to MP colleagues. The last two expressions of disagreement in particular are a regular part of the way PPGs operate, but their covert and non-public nature bars any systematic analysis of them. To use Erving Goffman's metaphor of the theatre - we will analyse the stage but not the backstage [Goffman 1999].

The data on unity and participation in voting based on analyses of all votes taken in the 1998-2002 electoral term of the Chamber of Deputies show the dominant voting pattern of Czech PPGs. The PPGs of the governing parties vote more in unison. In previous electoral terms, this pattern was disrupted only by the PPG of Republican Party (SPR-RSČ), which was ruled by an authoritarian party chair, and by the PPG of the Communist Party of Bohemia and Moravia (KSČM), which has a strong sense of partyness and loyalty. A similar pattern can also be observed with respect to participation in voting (see Tables 2 and 3).

It is clear from the tables that PPGs are relatively united in voting. The average score of the Rice Index of Party Cohesion is around 80 points, which means that in a PPG of ten members only one MP on average votes differently from the rest of the PPG. ${ }^{6}$ However, when compared to several Western European countries the val-

\footnotetext{
${ }^{6}$ The basic presumption of calculating the Rice Index is that in the case of a division of a PPG into equally numerous groups of MPs that stand against each other, the Index is 0 , and in the case of absolute unity Index is 100 . The index is calculated as the result of dividing the number of MPs in a PPG forming a majority in a given vote by the number of voting MPs. Then we take this figure and deduct 0.5 and multiply it by 2 .

Formula: $\mathrm{I}=((\mathrm{N}$ majority $/ \mathrm{N}$ whole PPG $)-0.5) * 2$
} 
Table 2. Party unity in the Chamber of Deputies (1994-2002) - Rice Index

\begin{tabular}{lcccc}
\hline $\begin{array}{l}\text { Years } \\
\text { (number of votes) }\end{array}$ & $\begin{array}{c}\mathbf{1 9 9 4 - 1 9 9 6} \\
\mathbf{( 5 1 0 5} \text { votes) }\end{array}$ & $\begin{array}{c}\mathbf{1 9 9 6 - 1 9 9 8} \\
\mathbf{( 4 7 8 3 ~ v o t e s )}\end{array}$ & $\begin{array}{c}\mathbf{1 9 9 8 - 2 0 0 2} \\
\mathbf{( 1 3} \mathbf{5 9 4} \text { votes) }\end{array}$ & $\begin{array}{c}\text { Selected votes* } \\
\text { (226 votes) }\end{array}$ \\
\hline ČSSD & 71.6 & 80.4 & $\mathbf{8 2 . 5}$ & $\mathbf{8 9 . 2}$ \\
KDU-ČSL & $\mathbf{8 2 . 4}$ & $\mathbf{8 7 . 4}$ & 78.4 & 87.2 \\
KSČM & 82.6 & 86.4 & 83.3 & 86.3 \\
ODS & $\mathbf{8 5 . 0}$ & $\mathbf{8 5 . 8}$ & 79.4 & 84.2 \\
US-DEU & - & 82.0 & 80.0 & 88.2 \\
ODA & $\mathbf{8 1 . 4}$ & $\mathbf{8 5 . 8}$ & - & - \\
SPR-RSČ & 93.4 & 97.4 & - & - \\
Average* & 82.7 & 86.5 & 80.7 & 87.0 \\
\hline
\end{tabular}

Source: Institute of Sociology, Academy of Sciences of the Czech Republic for the period 1998-2002; Kopecký, Hubáček and Plecitý [1996] for the period 1994-96; Linek [2002] for the period 1996-98.

* votes selected from the 7th, 8th and 9th session of Chamber of Deputies that concern amendment to the law or approval of the law [see Linek and Rakušanová 2002].

** non-weighted average; the ruling party is indicated in bold.

Table 3. Participation in voting in the Chamber of Deputies (1994-2002) (\%)

\begin{tabular}{lccc}
\hline $\begin{array}{l}\text { Years } \\
\text { (number of votes) }\end{array}$ & $\begin{array}{c}\mathbf{1 9 9 4 - 1 9 9 6} \\
\mathbf{( 5 1 0 5} \text { votes) }\end{array}$ & $\begin{array}{c}\mathbf{1 9 9 6 - 1 9 9 8} \\
\mathbf{( 4 7 8 3 ~ v o t e s )}\end{array}$ & $\begin{array}{c}\mathbf{1 9 9 8 - 2 0 0 2} \\
\mathbf{( 1 3} \mathbf{5 9 4} \text { votes) }\end{array}$ \\
\hline ČSSD & 64.2 & 87.0 & $\mathbf{8 5 . 3}$ \\
KDU-ČSL & $\mathbf{7 5 . 2}$ & $\mathbf{8 5 . 8}$ & 81.7 \\
KSČM & 76.0 & 90.6 & 86.1 \\
ODS & $\mathbf{7 4 . 4}$ & $\mathbf{8 4 . 6}$ & 85.4 \\
US-DEU & - & 75.4 & 76.3 \\
ODA & $\mathbf{6 6 . 4}$ & $\mathbf{8 2 . 8}$ & - \\
SPR-RSČ & 47.4 & 87.6 & - \\
Average* & 69.9 & 86.2 & 84.2 \\
\hline
\end{tabular}

Source: Institute of Sociology, Academy of Sciences of the Czech Republic for the period 1998-2002; Kopecký, Hubácek and Plecitý [1996] for the period 1994-6; Linek [2002] for the period 1996-1998.

* weighted average; the ruling party is indicated in bold.

ues of the Rice Index in the Czech Republic are relatively low (see Figure 2). We must however also bear in mind that there are pitfalls in making gross comparisons with other countries, as there are differences in the voting procedures and in the number and nature of analysed votes.

The relative disunity of Czech parliamentary party groups can also be illustrated from the answers MPs gave to the question of how they proceed in voting if 
Figure 2. Comparison of the unity of PPGs in selected countries - Rice Index

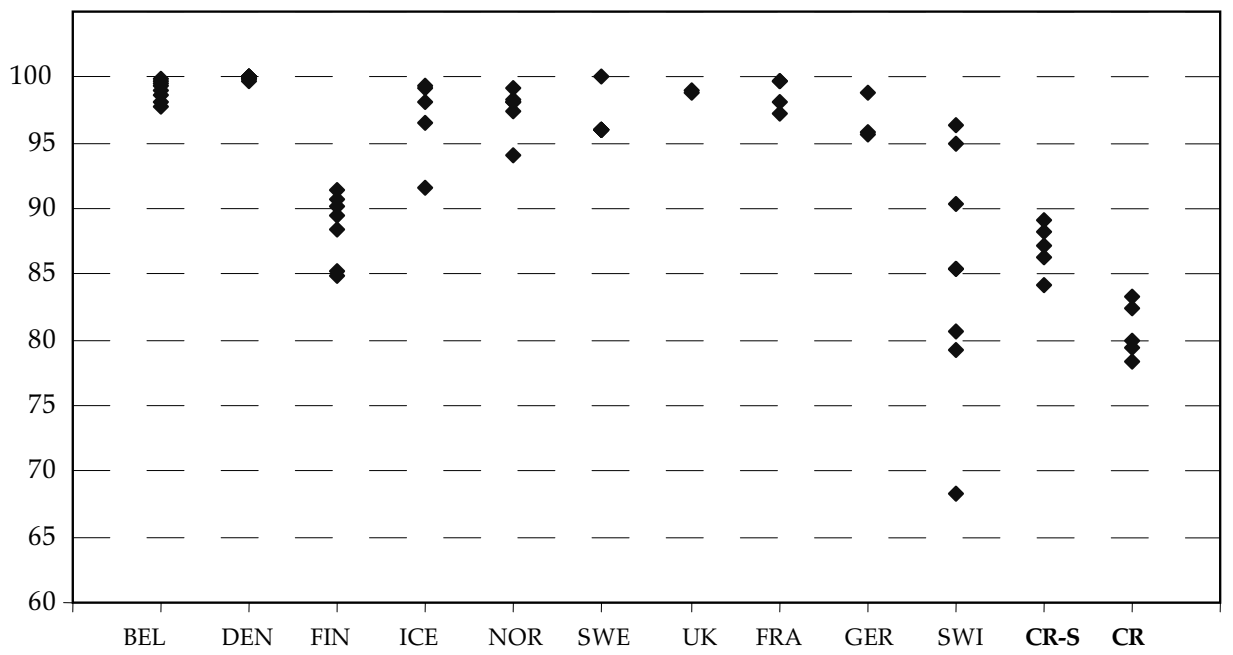

Source: DePauw [2002], only for the Czech Republic. Institute of Sociology, Academy of Sciences of the Czech Republic.

Note: The dots represent the values of the Rice Index for each party in the parliament of a particular country. The dots above CR-S represent the Rice Index values for the Czech parties in selected votes (see Table 2) and the dots above CR represent the Rice Index values for Czech parties in all votes during the studied period.

they do not agree with the position of their parliamentary party group (see Table 4). MPs of ČSSD, followed by those of ODS, voted most frequently according to the decision of the PPG, while MPs of other PPGs voted more according to their own opinion. However, MPs' answers to the general question about how they vote if they disagree with their PPG must be interpreted with caution. In the responses relating to individual public policies, MPs more often responded that they voted in unity with the PPG. Nevertheless, the data suggest that MPs retain a sufficient amount of manoeuvring space in voting.

Higher Rice Index values are attained for Czech PPGs when only those votes that directly influenced the shape of public policies formulated through bills are selected (votes on bills as a whole and votes on amendments to bills). There were approximately 7000 such votes in the 1998-2002 electoral term, and only votes from three consecutive sessions were chosen for a detailed analysis (sessions 7, 8 and 9 in the year 1998 and 1999). ${ }^{7}$ Nevertheless, these values are still below those of West-

\footnotetext{
7 The analysis looked at votes from three sessions, and session no. 7 was randomly selected as the first one. For a detailed methodology of the selection of votes, see Linek and Rakušanová [2002: 62].
} 
Table 4. How an MP usually votes in the case of disagreement with the PPG (\%)

\begin{tabular}{|c|c|c|c|c|c|}
\hline & ODS & US & KDU-ČSL & ČSSD & KSČM \\
\hline \multicolumn{6}{|l|}{ General } \\
\hline According to PPG & 42.6 & 18.8 & 12.5 & 69.8 & 27.3 \\
\hline According to one's opinion & 57.4 & 81.2 & 87.5 & 30.2 & 72.7 \\
\hline \multicolumn{6}{|l|}{ Constitutional bill } \\
\hline According to PPG & 64.8 & 52.9 & 56.2 & 90.8 & 90.5 \\
\hline According to one's opinion & 35.2 & 47.1 & 43.8 & 9.2 & 9.5 \\
\hline \multicolumn{6}{|l|}{ Budget } \\
\hline According to PPG & 68.5 & 82.3 & 56.2 & 92.2 & 85.7 \\
\hline According to one's opinion & 31.5 & 17.7 & 43.8 & 7.8 & 14.3 \\
\hline \multicolumn{6}{|l|}{ Other economic issues } \\
\hline According to PPG & 44.4 & 47.1 & 40.0 & 59.4 & 36.4 \\
\hline According to one's opinion & 55.6 & 52.9 & 60.0 & 40.6 & 63.6 \\
\hline \multicolumn{6}{|l|}{ Social policy } \\
\hline According to PPG & 48.1 & 43.8 & 21.4 & 63.5 & 59.1 \\
\hline According to one's opinion & 51.9 & 56.2 & 78.6 & 36.5 & 40.9 \\
\hline \multicolumn{6}{|l|}{ Foreign policy } \\
\hline According to PPG & 63.0 & 58.8 & 75.0 & 73.0 & 63.6 \\
\hline According to one's opinion & 37.0 & 41.2 & 25.0 & 27.0 & 36.4 \\
\hline \multicolumn{6}{|l|}{ EU Accession } \\
\hline According to PPG & 54.6 & 35.3 & 53.3 & 82.5 & 54.6 \\
\hline According to one's opinion & 45.4 & 64.7 & 46.7 & 17.5 & 45.4 \\
\hline
\end{tabular}

Source: Institute of Sociology, Academy of Sciences of the Czech Repubic, Survey of MPs in the year 2000.

Note: Answers to the question: 'A deputy may have a different opinion than his/her parliamentary party group; if so, how in your view should the deputy vote in general? And in other areas?'

ern European PPGs. The relatively low range of the Rice Index compared to Western European countries and the subjective perception of the manoeuvring space MPs have when voting on issues where they disagree with their PPG is especially striking considering the institutional drive toward unity and considering the number of tools that exist to enforce discipline among Czech MPs [see Linek and Rakušanová 2002: Chapter 3]. Moreover, these tools are not dramatically different from the tools available to parliamentary parties in Western Europe [see Bowler 2002; Heidar and Koole 2000a]. What are the reasons then behind the fact that PPGs in the Czech Republic are less united? And why do ruling parliamentary party groups not mind some disunity when voting on bills and on amendments to bills? 
If neither the outlined institutional relationships nor the mechanisms in Czech parties are behind the lack of unity, the answer must be sought elsewhere. Less cohesion within PPGs ${ }^{8}$ is not an explanation either, as the institutional rules and tools ought to be capable of ensuring party unity even when there is less cohesion.

In our opinion, the main reason lies in the nature of the coalition majorities that approve individual bills. Robert Golembiewski illustrated his concept of the power of political parties at the state level within the United States by showing that within parliament there is a strong relationship between the unity of political parties and the size of the majorities these parties have. According to Golembiewski [1958: 500-503], the larger the majority of a party, the less unity, and vice versa. Although Golembiewski used expert estimates of unity in individual state parliaments to measure unity, and indicators of political party power to measure the size of majorities (one of which is the number of seats the minority has in the parliament), his conclusions are persuasive and can be used here as a starting point to consider the relationships between unity and voting majorities in the Chamber of Deputies. If Golembiewski's argument is applied to a multi-party system with a coalition type of government, it is possible to hypothesise that the greater the coalition majority that approves bills, the less the unity within the parties comprising the coalition. In view of the only relative unity of Czech parliamentary party groups it is possible to expect that the relevant majorities that have approved bills have been large and not narrow.

The composition of the coalitions that approved individual bills in the course of the third electoral term (this calculation refers to the years 1998 to 2000 and the 304 bills debated during that period; see Table 5) reveals that the voting majorities were evenly balanced only in $15 \%$ of the cases (102:98). In the rest the majorities were so persuasive (no less than 113:87) that, in order to pass a bill, it was not necessary to enforce absolute party discipline among MPs. In the case of bills approved by the narrow margin of 102:98, nearly absolute unity is found in the PPGs. The hypothesis about the role of the size of majorities is further supported by the voting pattern in the previous electoral term (1996-1998). A right-of-centre coalition was in office for three quarters of that term, and at the beginning it had a minority of 99:101 and later a majority of $100+1$ unaffiliated MP to 99 . By comparing the voting unity in the periods 1996-1998 and 1998-2002 it becomes evident that during the period of the cabinet's narrow majority (1996-1998) the Rice Index was up 6 points (see Table 2).

The relationship between the unity of PPGs and the composition of the voting coalitions can be also considered from the opposite perspective. ${ }^{9}$ Less unity in PPGs is not the only consequence of the existence of large majorities in voting; the pre-

\footnotetext{
8 There is no data available on the attitudinal cohesion of PPGs (for example, from questionnaire surveys among MPs) that would allow for more exact claims to be made.

${ }_{9}$ Golembiewski also talked about the correlation between the unity of PPGs and the size of voting majorities, but not about a causal relationship.
} 
Table 5. Winning and losing majorities in the Chamber of Deputies (1998-2000)

\begin{tabular}{lcc}
\hline Winning voting coalition/losing voting coalition & Majority & \% \\
\hline ČSSD, KDU-ČSL, KSČM, ODS, US & $200: 0$ & 33.3 \\
ČSSD, KDU-ČSL, ODS, US versus KSČM & $176: 24$ & 20.0 \\
KDU-ČSL, ODS, US versus ČSSD, KSČM & $102: 98$ & 12.5 \\
ČSSD, KDU-ČSL, KSČM, US versus ODS & $137: 63$ & 11.0 \\
KDU-ČSL, KSČM, ODS, US versus ČSSD & $126: 74$ & 5.0 \\
ČSSD, KDU-ČSL, KSČM versus ODS, US & $118: 82$ & 5.0 \\
ČSSD, ODS versus KDU-ČSL, KSČM, US & $137: 63$ & 3.0 \\
ČSSD, KDU-ČSL, US versus KSČM, ODS & $113: 87$ & 3.0 \\
ČSSD, KSČM versus KDU-ČSL, ODS, US & $98: 102$ & 2.6 \\
ČSSD, KSČM, ODS versus KDU-ČSL, US & $161: 39$ & 2.6 \\
\hline
\end{tabular}

Source: Linek [2000].

Note: A total of 304 votes on all bills between 1998 and 2000 were analysed (these are votes that directly decided the existence of the bill - rejection of the act, passage of the act); for detailed methodology, see Linek [2000: 3]

dominance of large majority votes enabling the approval of bills may result from the fact that they involve lower transaction costs than the approval of bills by narrow margins. It is not easy for PPGs to secure absolute support for individual bills in each vote. Therefore, the leaders of PPGs may prefer votes with larger majorities. If a PPG leadership demands absolute support, it is clear that potential deviation from the party position should result in punishment (from the more lenient admonitions to the harshest punishment of expulsion from the party or a PPG). But punishment ultimately leads to a decrease in the number of PPG members, or at least to a decrease in the number of members willing to support a party, which is what political parties want least. The transaction costs associated with the narrow-margin approval of a bill lie in (1) ensuring unity, and, if unity has not been maintained, in (2) punishing those who deviated from the party position. Owing to the fact that PPGs are able to secure broader support for their proposals, they may insist on party unity only in cases that are of crucial importance for the party. Given that it is transactionally costly to vote by narrow margins in each vote, especially if there are thousands of votes each year, the leaderships of PPGs prefer the use of large majorities. This may be why most MPs are satisfied with the discipline in their PPG. In the survey, only the ruling party MPs (ČSSD) claimed that discipline should be greater (see Table 6).

In addition to lower transaction costs, there may be two other reasons why parties have taken advantage of large majorities to approve bills in the Chamber of Deputies. The first reason stems from the fact that some bills are considered technical bills. Political parties are able to pass some bills by a large majority because MPs 
Table 6. MPs' evaluations of party discipline (\%)

\begin{tabular}{lccc}
\hline Party & Should be stronger & Should remain the same & Should be weaker \\
\hline ČSSD & 50.5 & 39.1 & 9.4 \\
KDU-ČSL & 23.5 & 70.6 & 5.9 \\
KSČM & 18.2 & 81.8 & 0 \\
ODS & 12.5 & 80.4 & 7.1 \\
US & 25.0 & 75.0 & 0 \\
\hline
\end{tabular}

Source: Institute of Sociology, Academy of Sciences of the Czech Republic, Survey of MPs in the year 2000.

Note: Answers to the question: 'In your opinion, what are the requirements for party discipline in your parliamentary faction?'

interpret them as technical bills or because they are unable to interpret the content of some bills in terms of socio-economic cleavages or divisions - the single most important type of cleavage that shapes political conflict in the Czech Republic. In the surveyed period, the Chamber of Deputies debated a large number of bills (781 bills). The bills were often related to the effort to harmonise Czech law with the directives and resolutions of the European Community. A large portion of these acts can be interpreted as technical in that no alternatives to them were possible, and in fact because the boundaries were established by the European directives and resolutions and by the agreed harmonisation deadlines. The bills were not related to party conflict as such, or rather, political parties did not regard them as political. The second reason is related to the mechanism of the 'Opposition Agreement' (explained above), which, in allowing the existence of a minority ČSSD cabinet and ensuring that it could not be recalled, also resulted in numerous majority approvals or rejections of bills. ČSSD was consequently able to selectively seek support for individual bills and build voting coalitions with different parties. ${ }^{10}$

\section{Conclusion}

This article attempted to address the question of what factors lie behind the low level of voting unity in the Czech Parliament. To this end the authors employed two methods to explain party unity, with one approach viewing the main source of unity in the voting arena, and the other approach interpreting unity as a consequence of the effect of institutional rules and the rules of procedure within parliament. The authors' initial assumption that institutional factors within the parliament and political parties result in more unity in PPGs in the Czech Republic was not fully confirmed. Even though the institutional incentives are similar to those in Western Eu-

10 Čada, Hujer, Linek and Starý showed that between 1998 and 2002 different voting coalitions existed for individual sectors of public policy [Čada, Hujer, Linek and Starý 2002]. 
ropean countries, they do not secure the same level of voting unity within PPGs. In the end, the reason for the relatively low party unity (the Rice Index of Party Cohesion at the level of 80) was found to lie in the size of the voting coalitions that approved individual bills. Large majorities make it possible for PPGs not to act in absolute unity. Large majorities also result in lower transaction costs, which the parties would otherwise have to expend if they wanted to ensure the approval of bills by narrow-margin majorities. As the majority-margins attained in numerous votes indicate it is not a problem for Czech parties to secure absolute party unity. The problem is to ensure absolute unity when such a large number of votes are taking place.

A follow-up study of parliamentary politics in other electoral terms and a comparison of the results with other countries may reveal the extent to which the relatively low degree of unity of Czech PPGs between 1998 and 2002 was influenced by only temporary factors (the Opposition Agreement, the nature and number of debated bills) or by more permanent factors (the organisational structure of Czech parties and political institutions). In the introduction it was mentioned that party unity is assumed as a precondition for the functioning of the mechanisms of representation and accountability in parliamentary democracies. The question is whether the low degree of unity in voting in the Czech parliament in any way threatens the proper functioning of these mechanisms. Such a threat could occur were it found that the low level of voting unity stemmed from political institutions, that is, from functionally long-term factors. Observations thus far suggest that political institutions are more inclined to lead Czech parties toward a unified approach, and that it is the temporally limited factors (the number and nature of bills debated and the consequent use of large majorities) that reduce voting unity.

LUKÁŠ LINEK is a researcher in the Department of the Sociology of Politics at the Institute of Sociology AS CR and a graduate student in the Department of Sociology at the Faculty of Social Sciences, Charles University. His research focuses on electoral behaviour in multi-level systems, political participation and political parties.

PETRA RAKUŠANOVÁ is a researcher in the Department of the Sociology of Politics at the Institute of Sociology AS CR and a graduate student in the joint doctoral programme of the Institute of Sociology AS CR and the Department of Sociology at the Faculty of Social Sciences, Charles University. Her doctoral dissertation focuses on the impact of processes of transformation, europeanisation and globalisation on civil society in Central Europe. In her research she specialises in studying the functioning of democracy and its institutions, participation and citizenship. 


\section{References}

Bowler, Shaun, David M. Farell and Richard S. Katz. 1999. "Party Cohesion, Party Discipline, and Parliaments." Pp. 3-22 in Party Discipline and Parliamentary Government, edited by Shaun Bowler, David M. Farell, Richard S. Katz. Columbus, Ohio: The Ohio State University.

Bowler, Shaun. 2002. "Parties in Legislatures: Two Competing Explanations." Pp. 157-179 in Parties without Partisans. Political Change in Advanced Industrial Democracies, edited by Russel J. Dalton, Martin P. Wattenberg. Oxford: Oxford University Press.

Castles, Frances and R. Wildenmann (eds.). 1986. Visions and Realities of Party Government. Berlin: De Gruyter.

Crowe, Edward. 1983. "Consensus and Structure in Legislative Norms: Party Discipline in the House of Commons." The Journal of Politics 45: 907-931.

Čada, Karel, Marek Hujer, Lukáš Linek and Rostislav Starý. 2002. “Kdo si notoval a kdo na sebe křičel?" (Who Got Along and Who Were Shouting at Each Other?) Parlamentní zpravodaj 8 (6): 13-15.

DePauw, Sam. 2002. “On Watchdogs and Floating Hippopotami: Cohesive and Efficient Parliaments." Paper presented at the Conference on Political Parties, Parliamentary Committees, Parliamentary Leadership and Governance, Istanbul 23-26 June 2002, organised by IPSA Research Committee of Legislative Specialists and Turkish Political Science Association.

Foucault, Michel. 1975. Surveiller et Punir: Naissance de la Prison. Paris: Gallimard.

Gaines, Brian J. and Goeffrey Garrett. 1993. “The Calculus of Dissent: Party Discipline in the British Labour Government." Political Behavior 15 (2): 113-135.

Goffman, Erving. 1999 (1959). Všichni hrajeme divadlo. (Presentation of the Self in Everyday Life) Prague: Nakladatelství studia Ypsilon.

Golembiewski, Robert T. 1958. "A Taxonomic Approach to State Political Party Strength." Western Political Quarterly 11 (3): 494-513.

Hazan, Reuven Y. 2003. “Does Cohesion Equal Discipline? Towards a Conceptual Delineation." Special issue of the Journal of Legislative Studies on Cohesion and Discipline in Legislatures 9 (4): 1-11.

Heidar, Knut and Ruud Koole (eds.). 2000a. Parliamentary Party Groups in European Democracies. Political Parties behind Closed Doors. London, New York: Routledge.

Heidar, Knut and Ruud Koole. 2000b. "Parliamentary Party Groups Compared." Pp. 248-270 in Parliamentary Party Groups in European Democracies. Political Parties behind Closed Doors, edited by Knut Heidar and Ruud Koole. London, New York: Routledge.

Kolář Petr, Štěpán Pecháček and Jindřiška Syllová. 2002. Parlament České republiky 1993-2001. (The Parliament of the Czech Republic 1993-2001) Prague: Linde.

Kopecký, Petr, Pavel Hubáček and Petr Plecitý. 1996. "Politické strany v českém Parlamentu (1992-1996): organizace, chování, vliv." (Political Parties in the Czech Parliament (1992-1996): Organisation, Behaviour, Influence) Sociologický časopis 32 (4): 439-456.

Kopecký, Petr. 2000. "The Limits of Whips and Watchdogs in the Czech Republic." Pp. 177-194 in Parliamentary Party Groups in European Democracies, edited by Knut Heidar and Ruud Koole. London, New York: Routledge.

Kunc, Stanislav. 2001. "Poslanci a jejich platy." (Deputies and Their Salaries) Parlamentní zpravodaj 7 (8-9): 15-18.

Kysela, Jan. 2003. "Poslanecká sněmovna v ústavním systému České republiky.”

(The Chamber of Deputies in the Constitutional System of the Czech Republic) Pp. 2-16 in Volby do Poslanecké sněmovny $v$ roce 2002, edited by Lukáš Linek, Ladislav Mrklas, Adéla Seidlová and Petr Sokol. Prague: Institute of Sociology, Academy of Sciences of the Czech Republic. 
Linek, Lukáš. 2002. “Co dělají poslanecké kluby, když hlasují. Aneb loajalita a disciplína ve Sněmovně." (What Do Parliamentary Party Groups Do When They Vote, or Loyalty and Discipline in the Chamber of Deputies) Parlamentni zpravodaj 8 (6): 5-8.

Linek, Lukáš. 2001. “Factions in the Chamber of Deputies and the Senate." Pp. 57-67 in The Parliament of the Czech Republic 1993-1998: Factbook, edited by Lukáš Linek and Petra Šalamounová. Prague: Institute of Sociology, Academy of Sciences of the Czech Republic.

Linek, Lukáš. 2000. "Přes zdánlivé rozepře vítězí v Poslanecké sněmovně pragmatismus." (Despite Apparent Differences Pragmatism Rules the Chamber of Deputies) Parlamentní zpravodaj 6 (8-9): 2-4.

Linek, Lukáš and Petra Rakušanová. 2002. Parties in the Parliament. Why, When and How Do Parties Act in Unity? Parliamentary Party Groups in the Chamber of Deputies in the Years 1998-2002. Prague: Institute of Sociology, Academy of Sciences of the Czech Republic.

Mansfeldová, Z., 2002. "Das tschechische Parlament im Zeichen allmählicher Stabilisierung." Pp. 111-126 in Parlamente und Systemtransformation im Postsozialistischen Europa, edited by Susanne Kraatz and Silvia von Steinsdorff. Opladen: Leske and Budrich.

Mansfeldová, Zdenka and Ferdinand Müller-Rommel. 2001. “Czech Republic.” Pp. 62-72 in Cabinets in Eastern Europe, edited by Jean Blondel and Ferdinand Müller-Rommel. Houndsmills, Basingstoke, Hampshire: Palgrave.

Mulgan, Richard. 2003. Holding Power to Account. Accountability in Modern Democracies. Houndsmills, Basingstoke, Hampshire: Palgrave Macmillan.

Outlý, Jan. 2003. "Primárky ve volbách do Poslanecké sněmovny 2002." (Candidate Selection before the 2002 Elections to the Chamber of Deputies) Pp. 17-35 in Volby do Poslanecké sněmovny v roce 2002, edited by Lukáš Linek, Ladislav Mrklas, Adéla Seidlová and Petr Sokol. Prague: Institute of Sociology, Academy of Sciences of the Czech Republic.

Ozbundun, Ergun. 1970. Party Cohesion in Western Democracies: A Causal Analysis. Beverly Hills, CA: Sage.

Przeworski, Adam et al. 1999. Democracy, Accountability and Represenation. Cambridge: Cambridge University Press.

Saxonberg, Steven. 2003. The Czech Republic before the New Millennium: Politics, Parties and Gender. Boulder, New York: Columbia University Press.

Šimíček Vojtěch. 1996. "Povaha a právní postavení poslaneckých klubů v České republice." (The Nature and Legal Standing of Parliamentary Party Groups in the Czech Republic), Pp. 99-108 in Aktuální problémy parlamentarismu, edited by Vojtěch Šimíček. Brno: MPÚ.

Weber, Max. 1972 (1922). Wirtschaft und Gesellschaft. Grundrisse der verstehenden Soziologie. Tübingen. 